\title{
OVER DE BETEEKENIS VAN DEN NAAM SEMAR
}

DUOB

DR. H. H. JUYNBOLL.

Tot de meest bekende typen uit het Javaansche tooneel kan zeker wel Semar gerekend worden. Hij is niet alleen een eenvoudige nar of bediende, doch hij beschermt ook zijnen meester, die tot het geslacht der Panclawa's of hunne voorouders of nakomelingen behoort. Hij geeft steeds verstandigen raad en toont meer te weten van de plannen der goden en menschen clan zijn meester, die hem steeds raadpleegt in mueilijke omstandigheden: Volgens Hazeu ${ }^{1}$ is hij "een der echt-Javaansche voorouders, wier schimmen in het oude religieuse schimmenspel werden vertoond en een geliefde figuur uit de echt-Javaansche (of Mal-Polyn.) mythologie. In de Manik Ma!a $(I, \dot{T})$ is hij een incarnatie van Sang hyang Maya, den zoon ran Sang hyang Tunggal, den Oppergod. Verder zegt Hazeu, na ook eenige namen van clowns in de Balische wayang genoemd te hebben: "Hun namen schijnen alle zeer oud, evenals de naam Semar, omtrent welks beteekenis ik geen gissing clurf wagen. .

Indertijd heb ik in eene bespreking van eene hoogst belangrijke studie van pater Schmidt in het Archiv für Religionsgeschichte 2 de veronderstelling geopperd, dat de naam Sëmar zou beteekenen: "de stralencle", afgeleid van den stam sar, die o.a. deze beteekenis heeft. Als deze rooronderstelling juist was, 7.ou Semar dus oorspronkelijk een lichtgod geweest zijn. Deze verklaring is echter weinig bevredigend, omdat Sermar, voor zoover mij althans bekend is, nooit in deze functie optreedt.

Veel dichter bij cle waarheid komen Mr. L. Serrurier in het

1 Bijdrage tot de kennis van het Javannsche tooneel (1897), lpag. 112,

2 Band XVI (1913), pag. 216 (referast over Schmidt's Grundlinien einer Vergleichung der Religionen und Mytbologien der anstronesischen Völkes (Wien 1910). 
hoofdstuk "phallisme in de wajang, van zijne bekende monographie over de Wajang poerwa' ', doch vooral Prof. K. Th. Preuss in zijne zeer lezenswaardige verhandeling "Phallische Fruchtbarheits-Dämonen als Träger des altmexikanischen Dramas" ${ }^{2}$. Deze beide schrijvers vergelijken Semar met den held van het Turksche schimmenspel Karagös, die zooals dr. von Luschan ${ }^{3}$ dit uitdrukt "fast immer von Haus aus mit Priapismus behaftet auf cler Bühne erscheint». Als men de afbeeldingen, die Serrurier daar van de panah ing Semar geeft en de beschrijving van de wayang-pop Poting in den Catalogus van 's Rijks Ethnogr. Museum * vergelijkt met de vruchtbaarheidsdaemonen van het oud-Mexikaansche drama, komt men tot de gevolgtrekking, dat ook Semar oorspronkelijk een lentedaemon moet geweest zijn.

De etymologie van zijn naam duidt ook hierop. Semar of sumar is afgeleid van den wortel $s \bar{r} r$, die als substantief *uitbreiding, verspreiding" en als adjectief -talrijk, beteekent. Van denzelfden wortel is natuurlijk het overbekende Maleische woord bès ar "groot».

Voorbeelden van het gebruik van $s \bar{a} r$ in de Oudjavaansche literatuur zijn o. a.: Bhăratặuddha, XII, 1.j, waar van Bhișma's pijlen gezegd wordt: çarawara nira sār sök lu mrā ring tawang awilet: "zijne voortreffelijke pijlen waren talrijk en verspreidden zich in menigte in het luchtruim, al draaiende».

Ook de afgeleide vorm sumar beteekent meestal *zich verspreiden * en wordt dikwijls van geuren of van lichtstralen gebruikt, b.v. Rămă!aṇa, VIII, 27 wordt van de dewadăru gezegd: rumnı̀a sumrak umareng irung sumăr: "zijn geur drong door tot den neus, zich verspreidende." In het Àdiparwa (pag. 43) heet het van het vuur, dat den amrta omgeeft: yatikámarub sumirat sumār ing antarăla: "het schitterde en straalde, zich verspreidende in het luchtruim." In Bhāratayuddha, VI, 7 wordt weder gesproken van gand h a su ma $\mathrm{r}$ : "reuk die zich verspreidt .

Vooral belangrijk echter is eene plaats in den Irttasañcaya, vers 35 ; Kus uma katangga sumār, wordt daar door Prof. Kern vertaald met: (de $\mathrm{Katan} g \mathrm{~g}$ a-bloesems waren ontloken.,

1 In de to uitgare pag. 291 vlg. ( = pag. 187 vlg. der to editie).

- Archir für Anthropologie, Neue Folge. Band I (1908), pag. 129.188.

- Internat. Archiv für Ethnographief II' (1889), pag. 8.

- Deel XIII (1918), pag. 133. 
In de aanteekeningen op deze plaats (pag. 97) zegt prof. Kern, lat sumar of sumăr beantwoordt aan skr. sphuța, sphuțita en haar gelang van omstandigheden te vertalen is met barsten, ontluiken, aanbreken, in het oog springen.»

Hierin ligt, dunkt ons, eene aanwijzing, dat Semar (oorspronkelijk Sumār) de personiticatie van de ontluikende of aanbrekende lente was of m.a.w. een vruchtbaarheidsdaemon. Nu wordt het ons ook duidelijk, waarom de panah ing Semar met een stierenkop afgebeeld wordt. Immers zoowel de phallos als de stier waren ook bij de Indiërs symbolen van vruchtbaarheid. Men denke slechts aan den lingga en den $\mathrm{Nandi}$, die in den Ci iva-dienst zulk een voorname rol spelen. (lok de naam Çiwa is door sommige geleerden, o.a. Benfey (Indien, pag. 179) en I.assen (Indische Altertumskunde, I, pag. 923) van den wortel c u, çvi, die "wachsen, schwellen beteekent afgeleid. Deze afleiding worclt door andere geleerden (o.a. door L. von Schröder) betivist, doch als $7 . i j$ juist is, zou de overeenkomst met Semmar (de ontluikencle) treffend zijn. In elk geval kan men als een analogon verwijzen naar de vruchtbaarheidsdaemonen, die bij de tooneelvoorstellingen der oude Mexikanen zoo op den roorgrund treden. 